\title{
Prognostic potential of circulating miR-93-5p in patients with colorectal cancer liver metastases
}

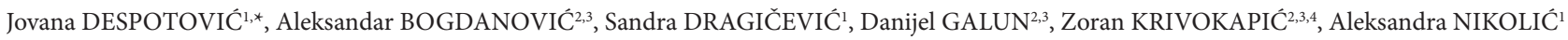 \\ ${ }^{1}$ Institute of Molecular Genetics and Genetic Engineering, University of Belgrade, Belgrade, Serbia; ${ }^{2}$ Clinic for Digestive Surgery, Clinical Center \\ of Serbia, Belgrade, Serbia; ${ }^{3}$ School of Medicine, University of Belgrade, Belgrade, Serbia; ${ }^{4}$ Serbian Academy of Sciences and Arts, Belgrade, \\ Serbia
}

${ }^{*}$ Correspondence: jovanadespotovic@imgge.bg.ac.rs

Received June 3, 2021 / Accepted September 7, 2021

\begin{abstract}
This study aimed to examine the expression pattern of tumoral and circulating miR-93-5p in patients with colorectal cancer (CRC) liver metastasis (CRLM) and to explore its predictive and prognostic potential. CRLM tissue, surrounding non-tumor liver tissue, and serum were obtained from 35 patients with CRLM. The expression pattern of tissue and circulating miR-93-5p in patients with CRLM was determined using quantitative polymerase chain reaction, using miR-16-5p for normalization. Sample-based cut-off values for CRLM and serum miR-93-5p expression were calculated using Receiver Operating Characteristic curve analysis to stratify the patients into high and low miR-93-5p expression groups which were that compared with patients' clinicopathological data, therapy response, one-year disease-free survival, and disease recurrence. Relative miR-93-5p expression was higher in CRLM in comparison to the non-metastatic liver tissue $(\mathrm{p}<0.001)$. CRLM miR-93-5p expression showed moderate negative correlation with carcinoembryonic antigen levels $(r=-0.406 ; p=0.016)$. There were no differences in high-/low-miR-93-5p expression and therapy responders vs. non-responders, which was confirmed in vitro using metastatic and normal colonic cells SW620 and HCEC-1CT, respectively. No difference was observed in one-year recurrence-free survival in patients with high vs. low miR-93-5p expression in CRLM or serum. However, high miR-93-5p serum levels were significantly associated with early disease recurrence $(\mathrm{p}=0.035)$. In conclusion, miR-93-5p serum levels could be potentially used as a prognostic factor for early disease recurrence in CRLM patients.
\end{abstract}

Key words: metastatic colorectal cancer, colorectal cancer liver metastasis, microRNA, miR-93-5p, prognostic biomarker

Colorectal cancer (CRC) takes third and second place in terms of incidence and mortality rates worldwide, respectively [1]. Approximately one-quarter of CRC patients are metastatic at the time of diagnosis (metastatic CRC, mCRC) [2]. Almost half of CRC patients will develop metastatic tumors eventually [3], with the liver being the most common target organ $[2,4]$. The presence and progression of colorectal cancer liver metastasis (CRLM) can be a life-limiting event since it accounts for approximately half of deaths in CRC patients, thus contributing to high CRC mortality rates [5]. Hepatic resection of colorectal cancer liver metastases is crucial for treatment and leads to a 5-year overall survival rate of up to $58 \%$ [6-8]. However, the majority (75-90\%) of metastatic CRC patients are not candidates for resection because of disease extent or severe comorbidities $[6,8]$. For this group of patients, systemic neoadjuvant chemotherapy is administrated with an aim to render unresectable disease resectable.
Systemic chemotherapy has long been the gold standard of chemotherapy for mCRC patients. Most commonly, 5-fluorouracil (5-FU) is combined with folinic acid and oxaliplatin (FOLFOX regime) [9], or with folinic acid and irinotecan (FOLFIRI regime) [10]. However, since 2004 the decision-making process regarding the choice of first-line therapy for mCRC has been complicated by the introduction of molecularly targeted biological agents: bevacizumab (the monoclonal antibody $(\mathrm{mAb})$ against vascular endothelial growth factor (VEGF)) and cetuximab and panitumumab (mAbs targeting epidermal growth factor receptor (EGFR)) [11]. Although mentioned biologicals improved survival rates in patients with mCRC and the overall survival is now in the 30-month range [12], cetuximab and panitumumab are only beneficial in KRAS/NRAS wild-type patients [13, 14], while for bevacizumab there are no validated predictive biomarkers available [3]. As, for prognostic biomarkers, 
it has been shown that BRAF mutant mCRC tumors had a poorer prognosis in comparison to $B R A F$ wild-type tumors [15]. Albeit the new biomarkers are rapidly emerging, the negative predictive role of RAS status for anti-EGFR therapy and the negative prognostic role of $B R A F$ mutations are currently the only ones with a clear clinical utility $[16,17]$. For this reason, it is imperative to find new predictive and prognostic biomarkers in order to personalize the treatment of patients with mCRC.

microRNAs (miRNAs) are small regulatory RNA molecules that direct posttranscriptional repression of mRNA targets [18]. Expression of miRNAs is altered in CRC in comparison to normal mucosa [19]. Furthermore, microRNA signatures are associated with the diagnosis, staging, progression, and prognosis of CRC [20]. Additionally, miRNAs expression has been associated with therapeutic response in CRC [21]. Having that previously in mind, and a fact that the miRNAs have high tissue specificity, stability, and altered expression in tumor development, miRNAs have been suggested as diagnostic, prognostic, and predictive biomarkers in CRC, both in tissue and as non-invasive circulating molecules in the blood [21-23].

miR-93-5p belongs to the miR-106b-25 cluster located at chromosome 7q22, in the intron 13 of the MCM7 gene [24]. There is no consensus regarding the direction of miR-93-5p expression in CRC in comparison to normal mucosa, with some studies showing that there is a downregulation of miR-93-5p $[25,26]$, while others show upregulated miR-93-5p expression [27]. Additionally, there are no consistent reports of whether miR-93-5p is an oncogenic [28] or a tumor-suppressor miRNA [29]. In our previous study, we have shown that expression of miR-93-5p was downregulated in response to chemotherapy for mCRC in SW620 cells [30]. Two studies have shown that decreased tumoral expression of miR-93 could be used as a novel prognostic factor for CRC $[25,31]$. However, the predictive or prognostic role of miR-93-5p in mCRC has not yet been elucidated. This study aimed to examine the expression pattern and predictive and prognostic potential of tumoral and circulating miR-93-5p in patients with CRLM.

\section{Patients and methods}

Subjects. In this study, thirty-five patients with CRLM were recruited between December 2016 and April 2019. All subjects were treated by curative-intent liver resection at the University Clinic for Digestive Surgery, Clinical Center of Serbia, Belgrade, Serbia. The subjects were included in the study if their age range was 18-90 and they had been treated for potentially curative hepatectomy for CRLM, simultaneously or after radical resection of a primary tumor. The exclusion criteria were previous hepatectomy for CRLM and the presence of residual extrahepatic disease. The study was approved by the Ethics Committee of the Clinical Center of Serbia. Informed consent was obtained from all individual participants included in the study. The study has been carried out in accordance with The Code of Ethics of the World Medical Association (Declaration of Helsinki) and its later amendments or comparable ethical standards.

Demographic and clinicopathological features recorded were age, sex, primary cancer data (localization, neoadjuvant/adjuvant chemo-radiotherapy, TNM, and Duke's classification), metastatic cancer data (neoadjuvant/adjuvant chemo-radiotherapy, number, diameter, and lobar distribution of liver metastases, presence of metastasis at diagnosis), carcinoembryonic antigen (CEA) and carbohydrate antigen (CA) 19-9, perioperative chemotherapy, tumor grading, and tumor residual status. Preoperative tumor staging was determined by transabdominal ultrasound, chest radiography, computed tomography (CT), and/or magnetic resonance imaging (MRI).

All patients were followed up for one year after surgery. Different diagnostic tests were performed at several time points in order to detect the possible recurrence of the disease. These tests included: measurement of the tumor markers CEA and CA 19-9 and transabdominal ultrasonography (every three months), CT and/or MRI (six months and one year after liver resection), while colonoscopy/rectoscopy and positron emission tomography were considered if local or distant recurrence was suspected. Early recurrence was defined as the presence of either recurrence at the site of primary cancer resection, appearance of new liver metastases, or extrahepatic disease one-year postoperation. Patients were further stratified into recurrence and no recurrence group in regard to the status of recurrent disease.

Samples from CRLM patients. In total, 105 samples were collected from 35 CRLM patients. CRLM and surrounding non-tumor liver tissue samples were obtained from resected liver immediately after surgery. Samples were straightaway immersed into RNAlater ${ }^{\oplus}$ RNA Stabilization Solution (Thermo Fisher Scientific, Lithuania) and stored at $-80^{\circ} \mathrm{C}$. Patients' whole blood samples were obtained one week before surgery. Whole blood samples were allowed to coagulate for $15 \mathrm{~min}$ at room temperature and then centrifuged at $3,500 \times \mathrm{g}$ for $10 \mathrm{~min}$. Obtained sera (supernatant) were aliquoted, once again centrifuged at $3,500 \times \mathrm{g}$ for $10 \mathrm{~min}$ to remove any possibility of contamination with blood cells and stored at $-80^{\circ} \mathrm{C}$ until RNA extraction.

In vitro cultivation and treatments of SW620 and HCEC-1CT cells. Human metastatic colon adenocarcinoma SW620 cells were grown in 10\% fetal bovine serumsupplemented Dulbecco's Modified Eagle Medium (Thermo Fisher Scientific, USA). Human colonic epithelial progenitor HCEC-1CT cells were purchased from Evercyte and grown in ColoUp medium (Evercyte, Austria) with $2 \%$ fetal bovine serum. Both cell lines were supplemented with $10 \mathrm{U} / \mu \mathrm{l}$ penicillin/streptomycin and cultured in $5 \% \mathrm{CO}_{2}$ humidified air at $37^{\circ} \mathrm{C}$. Cells were subcultured using $1 \times$ trypsin/EDTA (Sigma, USA) every third day. 
For the MTT assay, $1.5 \times 10^{4}$ SW620 cells and $6 \times 10^{3}$ HCEC-1CT cells were seeded per well in 96-well plates. Cells were left for $24 \mathrm{~h}$ to attach and for the next $72 \mathrm{~h}$ treated with FOX (21.4 $\mu \mathrm{M}$ 5-fluorouracil (5-FU) (EBEWE Pharma, Austria) and $85 \mu \mathrm{M}$ oxaliplatin (Actavis, Italy), as reported previously [30] or with 3 clinically relevant concentrations of bevacizumab (Avastin ${ }^{\circledast}$, Roche, Switzerland) based on its clinical pharmacokinetics analysis: $25 \mu \mathrm{g} / \mathrm{ml}$ (concentration below steady-state), $85 \mu \mathrm{g} / \mathrm{ml}$ (steady-state concentration) $[32,33]$, and $250 \mu \mathrm{g} / \mathrm{ml}$ (average concentration of maximal plasma concentration reported in Liston et al. [34] and Zhi et al. [33] or with FOX/bevacizumab combinations.

For miR-93-5p expression analysis, $5 \times 10^{5}$ SW620 and $2.5 \times 10^{5}$ HCEC-1CT cells were seeded in 6-well plates and treated on the next day with FOX, $250 \mu \mathrm{g} / \mathrm{ml}$ bevacizumab, or FOX $/ 250 \mu \mathrm{g} / \mathrm{ml}$ bevacizumab combination for $72 \mathrm{~h}$ and then lysed and collected with TRIzol reagent (Thermo Fisher Scientific, Lithuania) and stored at $-80^{\circ} \mathrm{C}$ until RNA extraction.

Generation of 5-FU resistant SW620. To make a clinically relevant model, which mimics the condition of $\mathrm{mCRC}$ patients experience during chemotherapy, 5-FU resistant SW620 cells (SW620 5-FUR) were developed by a stepwise increase of 5 -FU concentration $(5,10,15,20$, and $30 \mu \mathrm{M}$ 5 -FU, each treatment lasted 3 days) followed by a recovery period in a drug-free media (4 days). One-week cycle was repeated until the recovered cells formed a confluent layer in a T-75 flask. Cell sensitivity to different 5-FU concentrations (10-300 $\mu \mathrm{M}$ range) after $72 \mathrm{~h}$ was checked by MTT and $\mathrm{IC}_{50}$ values were determined for SW620 and SW620 5-FUR from 3 experiments. Fold resistance was calculated as $\mathrm{IC}_{50}$ SW620 5-FUR/IC 50 -SW620. SW620 5-FUR cells were generated during a 6-month period. SW620 5-FUR cells were maintained in $30 \mu \mathrm{M} 5$-FU, however, prior to experiments, cells were grown in drug-free media for one passage.

RNA extraction. Collected CRLM and non-tumor liver tissue were cut into smaller pieces and manually homogenized in $2 \times 0.5 \mathrm{ml}$ of TRIzol Reagent. Total RNA from tissue and cell culture was extracted according to the manufacturer's protocol, while the total RNA from serum was extracted using the protocol as previously described [35]. The concentration and purity of total RNA isolated from CRLM, liver tissue, and serum were determined by using BioSpec-nano spectrophotometer (Shimadzu, Japan).

miRNA expression analysis. Fifty nanograms (ng) of total RNA was reverse transcribed using a TaqMan MicroRNA Reverse Transcription Kit (Thermo Fisher Scientific, USA) according to the manufacturer's protocol and using the following program: $30 \mathrm{~min}$ at $16^{\circ} \mathrm{C}, 30 \mathrm{~min}$ at $42^{\circ} \mathrm{C}$ and 5 $\min$ at $85^{\circ} \mathrm{C}$.

Tissue, circulating and miR-93-5p expressed in cell lines were detected using TaqMan MicroRNA Assay ID 001090 (Thermo Fisher Scientific, USA), while miR-16-5p (Assay ID 001093) was used as endogenous control. In this study, miR-16-5p was used as a normalizer because it is highly expressed [36] and relatively stable in human cancer cell lines [37], various tumor samples, including CRC [38] and serum $[39,40]$. Quantitative reverse transcription-polymerase chain reaction (qRT-PCR) reactions were prepared by following the original protocol and run on a 7500 Real-Time PCR System (Applied Biosystems, USA). PCR conditions were $50^{\circ} \mathrm{C}$ for $2 \mathrm{~min}, 95^{\circ} \mathrm{C}$ for $10 \mathrm{~min}$, followed by 40 cycles of $95^{\circ} \mathrm{C}$ for $15 \mathrm{~s}$ and $60^{\circ} \mathrm{C}$ for $60 \mathrm{~s}$. Data were extracted by 7500 System Software and analyzed by $2^{\Delta \mathrm{Ct}}$ (patients) or $2^{-\Delta \Delta \mathrm{Ct}}$ method (cell culture). Each sample was run in triplicates. The criterion for reproducibility was set to 0.5 cycles [41]. This means that results for the biological sample were discarded or repeated when the $\mathrm{Ct}$ values of replicate reactions differed more than 0.5 cycles.

MTT assay. The viability of SW620 and HCEC-1CT cells was evaluated using the MTT assay. Cells were seeded and treated as described above. 3-[4,5-dimethylthiazol-2-yl]-2,5diphenyltetrazolium bromide (MTT) powder was dissolved in PBS. MTT solution was diluted in a medium in a final concentration of $0.5 \mathrm{mg} / \mathrm{ml}$ and was added to each well and incubated for $2 \mathrm{~h}$ at $37^{\circ} \mathrm{C}$ in the incubator. Afterward, the medium with MTT was discarded and cells were lysed in 100 $\mu \mathrm{l}$ DMSO for $30 \mathrm{~min}$. The absorbance was measured at 550 $\mathrm{nm}$ on the Infinite M200 PRO plate reader (TECAN, Switzerland). Data were analyzed using Magellan 7.2 software. Cells that were not incubated in MTT solution served as the blank. The percentage of cell survival was calculated using absorbance values (Abs) with the following formula: \% of viable cells $=\left(\left(\mathrm{Abs}_{\text {sample }}-\mathrm{Abs}_{\text {blank }}\right) /\left(\mathrm{Abs}_{\text {control }}-\mathrm{Abs}_{\text {blank }}\right)\right) \times 100$. Each experiment was repeated 3 times.

Statistical analysis. Statistical analysis was carried out using GraphPad Prism 9.0.0 (California, USA) and IBM SPSS Statistics 20.0 (Illinois, USA). Categorical variables were expressed as absolute numbers (percentages) while continuous variables were expressed as median (range) or mean \pm standard deviation (SD). In this study error bars (SD) are presented when there was a biological variation between treatments or groups and are not shown for technical replicates. Normal distribution was tested using KolmogorovSmirnov normality test. In the case of normally distributed data, Student's t-test or one-way ANOVA followed by Dunette's post hoc test was applied, and Pearson bivariate correlation coefficient was determined. Kruskal-Wallis's test, Mann-Whitney U test for two independent samples, or Wilcoxon signed-rank test were used whenever appropriate for non-normally distributed data. Also, nonparametric Spearman's rank correlation was determined for non-normal distributions. A p-value $\leq 0.05$ was considered statistically significant.

Receiver operating characteristic (ROC) curves were created to determinate sample-based cut-off values of miR-93-5p expression in CRLM and serum by Youden index (Youden index $=$ sensitivity + specificity -1 , larger test results indicate a more positive test for CRLM and serum miR-93-5p expression). Patients were stratified into the appropriate 
high-miR-93-5p and low-miR-93-5p groups based on the determined cut-off values. Kaplan-Meier method was used to estimate one-year recurrence-free survival of the highand low- miR-93-5p groups while the comparison was done using Log-rank test. Bivariate analysis was performed using Fisher's exact test for categorical variables to analyze prognostic factors affecting early recurrence.

\section{Results}

\section{Ex vivo analysis}

Study subjects. The clinicopathological characteristics of the primary and metastatic tumor of patients with CRLM included in this study are given in Table 1.

Regarding administration of neoadjuvant chemotherapeutic treatment for CRLM, 17 patients received 5-FU-based therapy in the form of FOLFOX-bevacizumab $(n=12)$, CAPOX-bevacizumab $(n=3)$, FOLFOX-CAPOX $(n=1)$, Capecitabine $(n=1)$, while one patient received cetuximabirinotecan as a second line therapy after first-line FOLFOXbevacizumab treatment. Response Evaluation Criteria in Solid Tumors (RECIST) version 1.1 guidelines were employed to evaluate objective tumor response after neoadjuvant chemotherapy for CRLM [42]. In brief, patients were first classified into complete response (CR, disappearance of all target lesions), partial response (PR, at least a 30\% decrease in the sum of diameters of target lesions), progressive disease (PD, at least a $20 \%$ increase in the sum of diameters of target lesions), and stable disease groups (SD, neither sufficient shrinkage to qualify for partial response nor sufficient increase to qualify for progressive disease). Patients were further classified into responders and non-responders. Responders included patients with $\mathrm{CR}$ and PR whereas non-responders included patients with SD or PD [43].

miR-93-5p expression in CRLM and non-metastatic liver. The miR-93-5p expression was evaluated in CRLM and non-metastatic liver of patients with mCRC. The expression of miR-93-5p was higher in 31/35 (88.6\%) patients, while $4 / 35$ (11.4\%) patients had lower miR-93-5p expression in comparison to the non-metastatic liver tissue (Figure 1A). As it can be observed in Figure 1B, the relative miR-93-5p expression was significantly higher in CRLM in comparison to the non-metastatic liver $(\mathrm{p}<0.001)$.

Estimation of cut-off values from ROC curve analysis. To stratify the patients into miR-93-5p high and low groups, Receiver Operating Characteristic (ROC) curve analysis and Youden's index were employed and sample-based cut-off values for CRLM and serum miR-93-5p expression were estimated. An optimal cut-off value for CRLM and serum miR-93-5p expression was 0.27 (sensitivity 62.5\%, specificity $57.9 \%$ ) and 0.04 (sensitivity $86.7 \%$, specificity $47.4 \%$ ), respectively. Patients were then divided into the high miR-93-5p expression group (higher miR-93-5p expression than the cut-off value) and the low miR-93-5p expression group (lower miR-93-5p expression than the cut-off value). Regarding miR-93-5p expression in CRLM, 18 (51.4\%) patients had high miR-93-5p expression and 17 (48.6\%) had low miR-93-5p expression, while in serum 23 (67.7\%) patients had high miR-93-5p expression and 11 (32.3\%) had low miR-93-5p expression.

Association of CRLM and serum miR-93-5p expression with clinicopathological characteristics of CRLM patients. To determine whether CRLM and serum levels of miR-93-5p were associated with clinicopathological characteristics, the CRLM patients were stratified by age and gender, number, maximal diameter, presence, lobar distribution and presentation of metastases, histological grade, residual status, and recurrence. There was no statistically significant association between miR-93-5p expression and clinicopathological characteristics of CRLM patients ( $\mathrm{p}>0.05$ for all).

Correlation of miR-93-5p expression in CRLM with its serum expression and tumor markers. To determine whether miR-93-5p expression in CRLM correlates with the serum miR-93-5p expression, Spearman's rank correlation coefficient was calculated. As shown in Figure 2A, there was no significant correlation between CRLM and serum miR-93-5p expression (Spearman's rho $(r)=0.166 ; p=0.349$ ). The correlation between miR-93-5p expression in CRLM
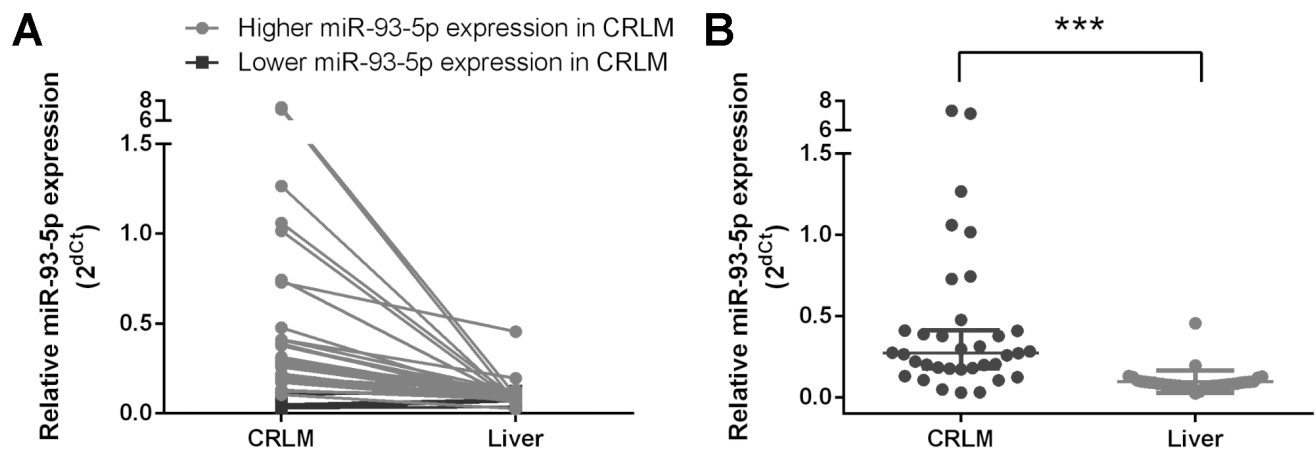

Figure 1. The expression of miR-93-5p in CRLM and non-metastatic liver of patients with mCRC. Relative expression levels $(2 \Delta C t)$ of miR-93-5p in CRLM and matched non-metastatic liver of mCRC patients shown as paired samples plot (A) and scatter plot $(\mathrm{B}) .{ }^{* * *} \mathrm{p}<0.001$ 
Table 1. The clinicopathological characteristics of patients with CRLM.

\begin{tabular}{|c|c|c|c|}
\hline & Study subjects $(n=35)$ & & Study subjects $(n=35)$ \\
\hline Age (years), mean $\pm \mathrm{SD}$ (range) & $63.7 \pm 12.2(24-84)$ & Therapy & \\
\hline Sex, N (\%) & & Neoadjuvant chemoradiotherapy & \\
\hline male & $19(54.3)$ & No & $29(82.9)$ \\
\hline female & $16(45.7)$ & Yes & $6(17.1)$ \\
\hline Tumor markers & & Adjuvant chemotherapy & \\
\hline $\mathrm{CEA}(\mathrm{ng} / \mathrm{ml})$, mean $\pm \mathrm{SD}$ (range) & $57.4 \pm 121.3(2-704)$ & No & $28(80.0)$ \\
\hline CA $19-9(\mathrm{IU} / \mathrm{ml})$, mean \pm SD $($ range $)$ & $669.7 \pm 2267.2(2-12999)$ & Yes & $7(20.0)$ \\
\hline Primary cancer information & $\mathbf{n}(\%)$ & CRLM information & n (\%) \\
\hline Site & II (7) & Number & \\
\hline Colon & & $\leq 3$ & $23(65.7)$ \\
\hline Colon & $14(40.0)$ & $>3$ & $12(34.3)$ \\
\hline Rectum & $21(60.0)$ & Maximal diameter & \\
\hline T stadium & & $\leq 5 \mathrm{~cm}$ & $27(77.1)$ \\
\hline $\mathrm{T} 1$ & $1(2.9)$ & $>5 \mathrm{~cm}$ & $8(22.9)$ \\
\hline $\mathrm{T} 3$ & $24(68.6)$ & Lobar distribution & \\
\hline $\mathrm{T} 4$ & $10(28.6)$ & Unilobar & $20(57.1)$ \\
\hline $\mathrm{N}$ stadium & & Bilobar & $15(42.9)$ \\
\hline No & $8(22.9)$ & Presentation & \\
\hline N1 & $16(45.7)$ & Synchronous & $25(71.4)$ \\
\hline $\mathrm{N} 2$ & $11(31.4)$ & Metachronous & $10(28.6)$ \\
\hline L stadium & & Presence & \\
\hline L0 & $10(28.6)$ & Solitary & $15(42.9)$ \\
\hline L1 & $25(71.4)$ & Multiple & $20(57.1)$ \\
\hline V stadium & & Histologic grade & \\
\hline V0 & $8(22.9)$ & Well differentiated (G1) & $16(45.7)$ \\
\hline $\mathrm{V} 1$ & $27(77.1)$ & Moderately differentiated (G2) & $19(54.3)$ \\
\hline R stadium & $27(7 / .1)$ & Residual status & \\
\hline K stadium & & R0 & $10(28.6)$ \\
\hline R0 & $30(85.7)$ & $\mathrm{R} 1$ & $25(71.4)$ \\
\hline R1 & $5(14.3)$ & Therapy & \\
\hline PN stadium & & Neoadjuvant chemotherapy & \\
\hline PN0 & $16(45.7)$ & No & $18(51.4)$ \\
\hline PN1 & $19(54.3)$ & Yes & $17(48.6)$ \\
\hline Duke's classification & & Adjuvant chemotherapy & \\
\hline $\mathrm{A}-\mathrm{B}$ & $3(8.6)$ & No & $16(45.7)$ \\
\hline $\mathrm{C}-\mathrm{D}$ & $32(91.4)$ & Yes & $19(54.3)$ \\
\hline
\end{tabular}

Abbreviations: n-number of patients, SD-standard deviation, T-tumor, N-node, L-lymphatic vessels invasion, V-vein invasion, R-resection, PN-perineural invasion, CRLM-colorectal liver metastasis, CEA-carcinoembryonic antigen, CA-carbohydrate antigen

or serum with tumor markers CEA and CA 19-9 was also analyzed. There was statistically significant moderate negative correlation between CRLM miR-93-5p expression and CEA levels $(r=-0.406 ; p=0.016$, Figure 2B). However, there was no significant correlation between serum miR-93-5p expression and CEA $(r=-0.112 ; \mathrm{p}=0.528)$ or CRLM and serum miR-93-5p expression and CA 19-9 levels $(r=-0.067 ; p=0.703$ and $\mathrm{r}=-0.187 ; \mathrm{p}=0.291$, respectively).

Predictive potential of miR-93-5p. Out of 35 patients, 17 (48.6\%) received neoadjuvant chemotherapy for metastatic disease. To explore whether administration of neoadjuvant chemotherapy has an effect on miR-93-5p expression, we compared CRLM and serum miR-93-5p expression in patients who received neoadjuvant chemotherapy with those who have not, and there was no statistical significance ( $\mathrm{p}>0.05)$. Based on RECIST criteria, 10 patients $(58.8 \%)$ had PR, 6 (35.3\%) SD, and 1 (5.9\%) PD, thus there were 10 responders and 7 non-responder patients. To evaluate the predictive value of miR-93-5p, it was analyzed whether high or low miR-93-5p expression in CRLM and serum corresponds to the patient's therapy response. However, there was no statistically significant association between high-/ low-miR-93-5p expression in CRLM or serum and whether the patient responded or not to therapy $(\mathrm{p}>0.05)$.

Prognostic potential of miR-93-5p for recurrencefree survival. Kaplan-Meier method was used to estimate 
A

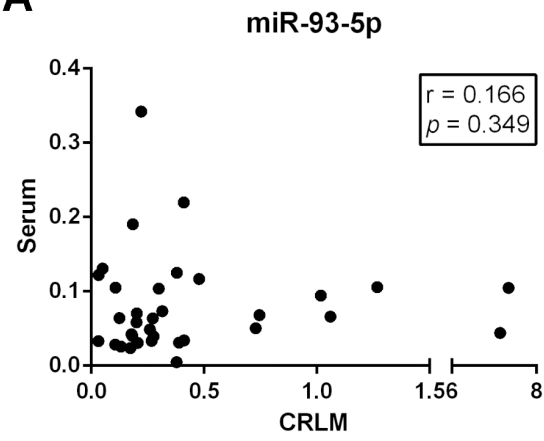

C

Expression of miR-93-5p in CRLM

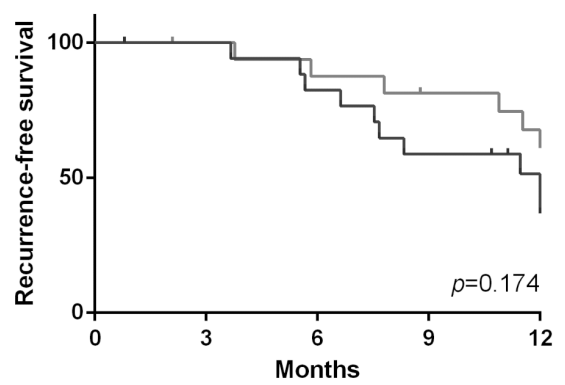

B

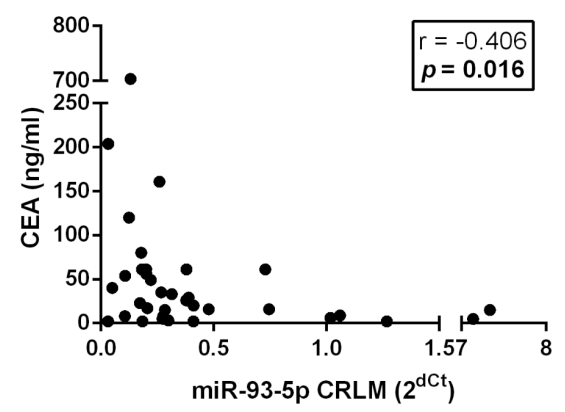

D

\section{Expression of miR-93-5p in serum}

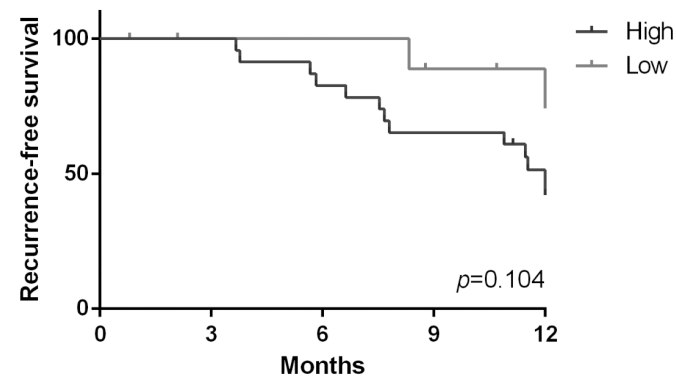

Figure 2. Expression of miR-93-5p in CRLM and serum - correlation with tumor markers and Kaplan-Meier analysis. Scatter plot representation of correlation of miR-93-5p expression in CRLM and serum (A), and miR-93-5p expression in CRLM and CEA tumor markers levels (B). Kaplan-Meier curves of one-year recurrence-free survival for high- and low- miR-93-5p groups based on CRLM (C) and serum (D) expression. Abbreviation: rSpearman's rank correlation coefficient

one-year recurrence-free survival of the high- and lowmiR-93-5p groups. There were no differences in one-year recurrence-free survival of patients with high miR-93-5p expression in CRLM and serum than in patients with low miR-93-5p expression $(\mathrm{p}=0.174$ and $\mathrm{p}=0.104$, respectively, Figures 2C, 2D).

Prognostic potential of miR-93-5p and clinicopathological characteristics of CRLM patients for early recurrence. Bivariate analysis was performed to evaluate the prognostic significance of miR-93-5p and clinicopathological characteristics of CRLM patients for early recurrence. As shown in Table 2, only serum miR-93-5p level was significantly associated with early recurrence, specifically, higher miR-93-5p expression was associated with more patients with recurrent disease, $\mathrm{p}=0.035$ ). Since serum miR-93-5p level was the only prognostic factor associated with recurrence, multivariate analysis was not performed.

\section{In vitro analysis}

To study the effect of systemic, targeted, and combinational therapy for CRLM on normal and metastatic CRC cells and on miR-93-5p expression in more detail, and to confirm the clinical findings, in vitro experiments were performed. Since the majority of CRLM patients (15 out of
17) received neoadjuvant treatment in the form of a 5-FU/ oxaliplatin/bevacizumab combination, these drugs were used in vitro.

Effects of FOX alone or in combination with bevacizumab on the viability of SW620 and HCEC-1CT cells. To study the effects of systemic, targeted, and combination of systemic and targeted therapy for CRLM patients in vitro, SW620 and HCEC-1CT cells were treated with FOX, 25, 85, and $250 \mu \mathrm{g} / \mathrm{ml}$ bevacizumab or with a FOX/bevacizumab combination, respectively and the cell survival was analyzed using MTT assay. As it can be observed from Figures $3 \mathrm{~A}$ and $3 \mathrm{~B}$, FOX treatment alone was able to reduce the cell survival of SW620 to $78.0 \pm 11.0 \%(\mathrm{p}=0.029)$ and of HCEC-1CT cells to $71.1 \pm 4.9 \%(\mathrm{p}<0.001)$. Increasing concentrations of bevacizumab had no effect on SW620 viability, whereas the viability of HCEC-1CT cells was reduced to $84.4 \pm 2.9 \%$ by $85 \mu \mathrm{g} / \mathrm{ml}$ bevacizumab $(\mathrm{p}=0.033)$ and to $87.4 \pm 9.3 \%$ by $250 \mu \mathrm{g} / \mathrm{ml}$ bevacizumab ( $\mathrm{p}=0.048$ ). As for combined FOX/ bevacizumab treatments, only FOX $/ 250 \mu \mathrm{g} / \mathrm{ml}$ bevacizumab was able to significantly reduce the viability of SW620 cells to $47.6 \pm 3.1 \%(\mathrm{p}=0.003)$, while FOX/85 $\mu \mathrm{g} / \mathrm{ml}$ bevacizumab and $\mathrm{FOX} / 250 \mu \mathrm{g} / \mathrm{ml}$ bevacizumab reduced the viability of HCEC-1CT cells to $40.6 \pm 10.1 \%(\mathrm{p}=0.003)$ and $37.9 \pm 6.4 \%$ $(\mathrm{p}=0.002)$, respectively. 
miR-93-5p expression in response to FOX alone or in combination with bevacizumab in SW620 and HCEC-1CT cells. It was already shown that neoadjuvant chemotherapy does not affect CRLM miR-93-5p levels (section Predictive potential of miR-93-5p) in mCRC patients, thus an in vitro experiment was set up to confirm this finding.

Basal miR-93-5p expression was determined in SW620 and HCEC-1CT cells cultured for $72 \mathrm{~h}$. miR-93-5p expression was higher in SW620 cells in comparison to the HCEC-1CT cells $(p<0.001$, Figure $3 C)$. Since only the highest tested concentration of bevacizumab $(250 \mu \mathrm{g} / \mathrm{ml})$ in combination with FOX was able to significantly reduce the viability of both SW620 and HCEC-1CT cells (Figures 3A, $3 \mathrm{~B})$, this concentration was used to analyze if the bevacizumab alone, or in combination with FOX, affects miR-93-5p expression. As shown in Figure 3D, FOX, $250 \mu \mathrm{g} / \mathrm{ml}$ bevacizumab nor FOX $/ 250 \mu \mathrm{g} / \mathrm{ml}$ bevacizumab combination had an effect on miR-93-5p expression ( $p>0.05$ ) in SW620 cells. However, in HCEC-1CT cells (Figure 3E), FOX decreased the miR-93-5p expression by $22.8 \pm 9.2 \%(\mathrm{p}<0.008)$, as well as a FOX $/ 250 \mu \mathrm{g} / \mathrm{ml}$ bevacizumab combination by $23.7 \pm 5.3 \%$ $(\mathrm{p}<0.006)$, while the $250 \mu \mathrm{g} / \mathrm{ml}$ bevacizumab had no effect on miR-93-5p expression ( $\mathrm{p}=0.79)$.

Expression of miR-93-5p in SW620 5-FU resistant cells. All of our study group subjects have received some form of 5-FU-based chemotherapy for CRLM. Patient data showed that there was no statistically significant association between miR-93-5p expression and therapy responders vs. non-responders. To confirm this, we have made an in vitro 5-FU-resistant mCRC model.

To generate 5-FU resistant SW620 cells, parental SW620 cells were treated with increasing concentrations of 5-FU ranging from 5 to $30 \mu \mathrm{M}$. After 6 months, the obtained cell sensitivity was checked by MTT and dose-response curves were generated (Figure 3F), and fold resistance was calculated based on $\mathrm{IC}_{50}$ values of parental and 5-FU resistant SW620 cells. The average $\mathrm{IC}_{50}$ of parental SW620 was 196.34 $\mu \mathrm{M}$, whereas the average $\mathrm{IC}_{50}$ of SW620 5-FU resistant cells was $351.11 \mu \mathrm{M}$. Fold resistance was approximately 1.8 .

To analyze if miR-93-5p is associated with resistance to 5-FU, miR-93-5p expression was measured in 5-FU resistant SW620 cells. As it can be observed in Figure 3G, there was no statistically significant difference in miR-93-5p expression in the parental SW620 cells in comparison to the 5-FU resistant SW620 cells.

\section{Discussion}

The predictive and prognostic role of miR-93-5p in mCRC has not been studied before. This study aimed to examine the predictive and prognostic potential of miR-93-5p expressed in CRLM and circulating miR-93-5p in serum in the same patients with CRLM.

To analyze the clinical significance of miR-93-5p in mCRC, miR-93-5p expression was evaluated in 35 paired
Table 2. Bivariate analysis of potential prognostic factors for early recurrence in patients with CRLM $(\mathrm{N}=35)$.

\begin{tabular}{|c|c|c|c|}
\hline $\begin{array}{l}\text { Characteristics of } \\
\text { mCRC patients and CRLM }\end{array}$ & $\begin{array}{c}\text { No Recurrence } \\
\mathrm{N}=19(54.3 \%)\end{array}$ & $\begin{array}{c}\text { Recurrence } \\
\mathrm{N}=16(45.7 \%)^{*}\end{array}$ & p-value \\
\hline \multicolumn{4}{|l|}{ Age } \\
\hline$\leq 65$ & $7(36.84 \%)$ & $7(43.75 \%)$ & 0.739 \\
\hline$>65$ & $12(63.16 \%)$ & $9(56.25 \%)$ & \\
\hline \multicolumn{4}{|l|}{ Gender } \\
\hline male & $10(52.63 \%)$ & $9(56.25 \%)$ & 1.000 \\
\hline female & $9(47.37 \%)$ & $7(43.75 \%)$ & \\
\hline \multicolumn{4}{|l|}{ Number of metastases } \\
\hline$\leq 3$ & $12(63.16 \%)$ & $11(68.75 \%)$ & 1.000 \\
\hline$>3$ & $7(36.84 \%)$ & $5(31.25 \%)$ & \\
\hline \multicolumn{4}{|l|}{ Maximal diameter } \\
\hline$\leq 5 \mathrm{~cm}$ & $14(73.68 \%)$ & $13(81.25 \%)$ & 0.700 \\
\hline$>5 \mathrm{~cm}$ & $5(26.32 \%)$ & $3(18.75 \%)$ & \\
\hline \multicolumn{4}{|l|}{ Presence } \\
\hline solitary & $9(47.37 \%)$ & $6(37.5 \%)$ & 0.734 \\
\hline multiple & $10(52.63 \%)$ & $10(62.5 \%)$ & \\
\hline \multicolumn{4}{|l|}{ Lobar distribution } \\
\hline unilobar & $11(57.9 \%)$ & $9(56.25 \%)$ & 1.000 \\
\hline bilobar & $8(42.1 \%)$ & $7(43.75 \%)$ & \\
\hline \multicolumn{4}{|l|}{ Presentation } \\
\hline synchronous & $11(57.9 \%)$ & $14(87.5 \%)$ & 0.071 \\
\hline metachronous & $8(42.1 \%)$ & $2(12.5 \%)$ & \\
\hline \multicolumn{4}{|l|}{ Histologic grade } \\
\hline G1 & $11(57.9 \%)$ & $5(31.25 \%)$ & 0.176 \\
\hline G2 & $8(42.1 \%)$ & $11(68.75 \%)$ & \\
\hline \multicolumn{4}{|l|}{ Residual status } \\
\hline R0 & $5(26.32 \%)$ & $5(31.25 \%)$ & 1.000 \\
\hline $\mathrm{R} 1$ & $14(73.68 \%)$ & $11(68.75 \%)$ & \\
\hline \multicolumn{4}{|l|}{ Sidedness of the primary tumor } \\
\hline left & $15(78.95 \%)$ & $13(81.25 \%)$ & 1.000 \\
\hline right & $4(21.05 \%)$ & $3(18.75 \%)$ & \\
\hline \multicolumn{4}{|l|}{ miR-93-5p in CRLM } \\
\hline low & $11(57.9 \%)$ & $6(37.5 \%)$ & 0.315 \\
\hline high & $8(42.1 \%)$ & $10(62.5 \%)$ & \\
\hline \multicolumn{4}{|l|}{ miR-93-5p in serum } \\
\hline low & $9(47.37 \%)$ & $2(13.33 \%)$ & 0.035 \\
\hline high & $10(52.63 \%)$ & $13(86.67 \%)$ & \\
\hline
\end{tabular}

Note: ${ }^{*}$ except for miR-93-5p in serum recurrence group $\mathrm{N}=15$

samples of CRLM and non-metastatic liver tissues of CRLM patients. The relative miR-93-5p expression was significantly higher in CRLM in comparison to the non-metastatic liver. To interpret this result, it is necessary to compare desired miRNA expression between the normal colon and normal liver tissue [44]. Expression of miR-93-5p was also higher in the normal colon in comparison to the normal liver tissue [45] thus no new information about miR-93-5p involvement in the metastatic process was observed. Another study reported higher miR-93-5p levels in CRLM, but the comparison was done with respect to the normal colon tissue [46]. Association of CRLM and serum miR-93-5p expression 
A

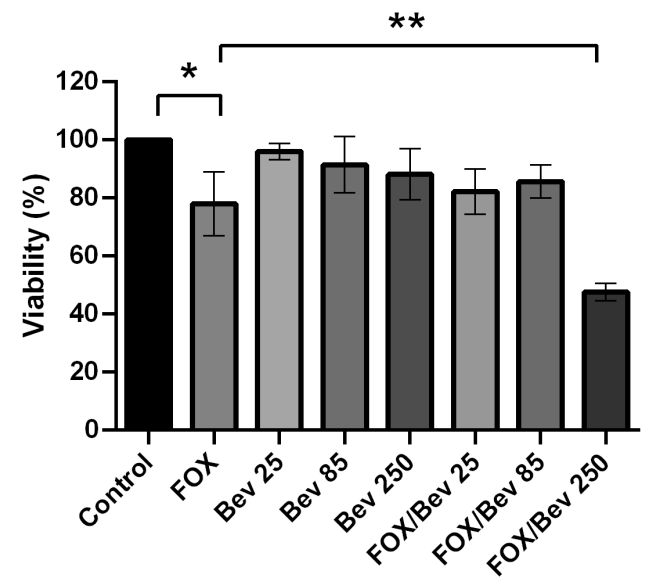

C

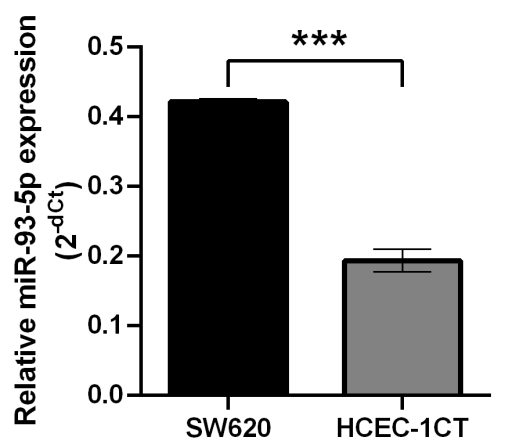

D

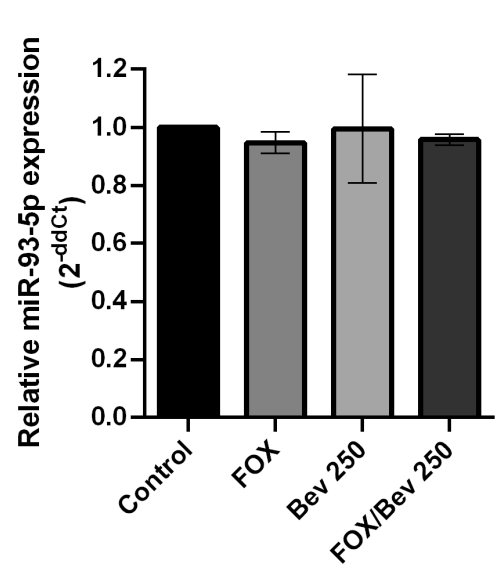

B

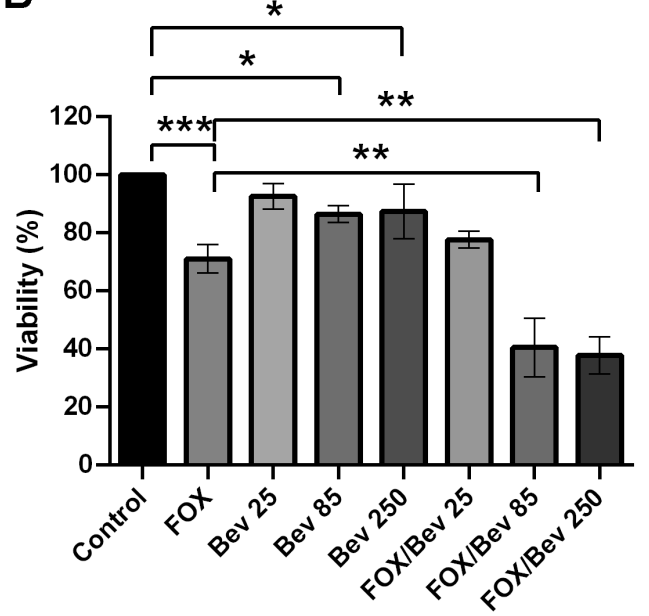

E

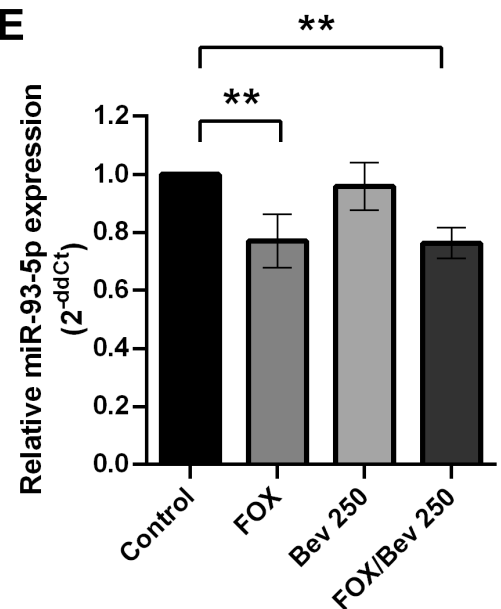

F

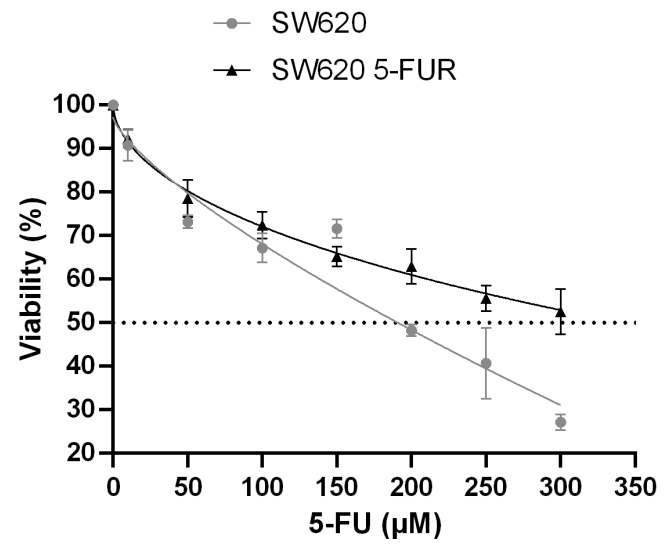

G

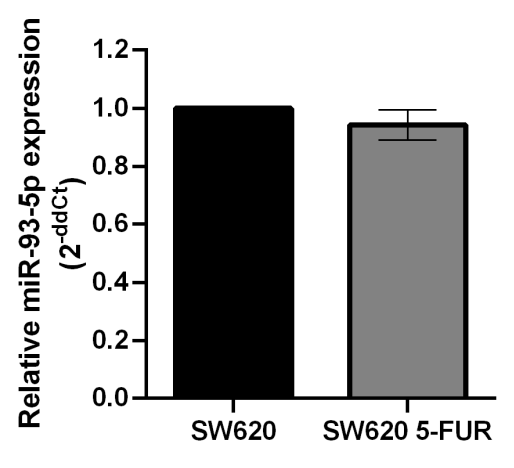

Figure 3. Viability of SW620 and HCEC-1CT cells and miR-93-5p expression in basal state and under treatments. Treatment of SW620 (A, D) and HCEC-1CT (B, E) with FOX, bevacizumab, or with a FOX/bevacizumab combination for $72 \mathrm{~h}$ and analysis of cell viability (\%) by MTT assay (A, B) and relative miR-93-5p expression (2- $\Delta \Delta \mathrm{Ct}$ ) by qRT-PCR (D, E). In one-way ANOVA analysis (A, B), bev 25, bev 85, and bev 250 treatments were compared to control treatment, while FOX/bev 25, FOX/bev 85, and FOX/bev 250 were compared to FOX treatment. C) Basal miR-93-5p expression in SW620 and HCEC-1CT cells cultured for $72 \mathrm{~h}$. F) Sensitivity of parental and 5-FU resistant SW620 cells to 5-FU. Parental and 5-FU resistant SW620 cells were treated with $0,10,50,100,150,200,250$, and $300 \mu \mathrm{M} 5$-FU for $72 \mathrm{~h}$ and cell viability (\%) was analyzed by MTT. G) Relative miR-93-5p expression $(2-\Delta \Delta \mathrm{Ct})$ was measured by $\mathrm{qRT}-\mathrm{PCR}$ in parental and 5-FU resistant $\mathrm{SW620}$ cells. Data are shown as mean \pm standard deviation. ${ }^{\star} \mathrm{p}<0.050$; ${ }^{\star *} \mathrm{p}<0.010$; ${ }_{* * *}<<0.001$. Abbreviations: bev 25-bevacizumab $25 \mu \mathrm{g} / \mathrm{ml}$; bev 85 -bevacizumab $85 \mu \mathrm{g} / \mathrm{ml}$; bev 250-bevacizumab $250 \mu \mathrm{g} / \mathrm{ml}$, SW620 5-FUR-SW620 5-FU resistant cells 
with clinicopathological characteristics of CRLM patients was also analyzed, and no association was found. However, in CRC patients low miR-93 expression was significantly correlated with advanced tumor stage and positive nodal and distant metastases [25], and with the poor tumor differentiation, presence of lymphatic metastasis, and higher TNM and Duke's stages [26].

miRNAs are released from cells into body fluids, and it is possible to detect them as stable circulating molecules in the blood [47]. The circulating miRNAs have been highlighted by numerous studies as a promising non-invasive tool for early detection, prognosis, and therapy selection of CRC patients [48]. There is a limited number of studies, which look for correlation of CRLM and serum miRNA expression in the same patients [49], although this approach could suggest if the changes in circulating miRNA patterns are derived from the tumoral mass or some other source [50]. To explore this, CRLM miR-93-5p levels were correlated with its serum expression, however, no significant correlation was found. CEA and CA 19-9 are well-established tumor markers for detection of disease recurrence, while the combination of these tumor markers with miRNAs could improve the discrimination between patients with favorable and unfavorable outcomes [47]. Thus, we correlated CRLM and serum miR-93-5p levels with tumor markers, and a moderate negative correlation between CRLM miR-93-5p expression and CEA levels was observed. Further studies should clarify the potential benefit of combining standard tumor markers, such as CEA, with miR-93-5p for better prognosis estimation.

miRNAs have been reported as promising tissues and blood biomarkers for the prediction of response to systemic and targeted therapy in CRC patients [51]. Our previous study showed that miR-93-5p was downregulated long-term under 5-FU, oxaliplatin, irinotecan, and 5-FU/oxaliplatin and 5-FU/irinotecan combinations in SW620 cells [30]. Hence, we first examined if the CRLM and serum miR-93-5p expression was altered in patients who received 5-FU-based neoadjuvant chemotherapy with regard to those who have not. Since we did not observe a significant difference, it can be concluded that 5-FU-based neoadjuvant chemotherapy does not affect CRLM and serum miR-93-5p expression in mCRC patients. Next, the predictive value of miR-93-5p was evaluated in patients with CRLM. No significant association was observed between high-/low-miR-93-5p expression in CRLM or serum between therapy responders and non-responders. This was in concordance with the study by Rasmussen et al. involving $\mathrm{mCRC}$ patients receiving XELOX/FOLFOX as first-line treatment [52]. Hence, we would argue that miR-93-5p does not have predictive value in CRLM patients treated with 5-FU- or oxaliplatin-based chemotherapy.

miRNAs have also been associated with prognosis and disease recurrence in CRC patients [22, 51]. The lower miR-93-5p expression has been previously associated with early relapse and worse overall and disease-free survival in
CRC patients $[26,27,31]$. Here, we have shown that there were no differences in one-year recurrence-free survival of patients with high miR-93-5p expression in CRLM and serum than patients with low miR-93-5p expression, however, high miR-93-5p serum levels were significantly associated with disease recurrence in CRLM patients. Hence, miR-93-5p serum expression could be potentially used as a prognostic factor for early disease recurrence but not for recurrence-free survival.

Several studies have been published previously which investigated the role of miR-93-5p on CRC tumorigenesis, as well as on migratory and invasive properties of CRC cell lines. The tumor-suppressive role of miR-93-5p was shown on proliferation, cell cycle regulation and apoptosis, migration, invasion, and tumor growth in vivo. Overexpression of miR-93-5p significantly inhibited cell proliferation and colony formation of SW1116 human colon cancer stem cells grown in the media without serum [53], SW480 and HCT116 cells by regulating the $\mathrm{Wnt} / \beta$-catenin signaling pathway [54,55], as well as of LOVO and SW480 cells through the miR-93-5p/HMGB3 regulatory axis [56], and Caco2 cells by regulating the expression of ERBB2, p21, and VEGF [27]. Functional studies showed that increased miR-93-5p expression promotes apoptosis of SW480 and HCT116 cells [55], SW480 and LOVO cells [56], and leads to the G2 phase accumulation of $\mathrm{Caco} 2$ cells [27]. Additionally, increased expression of miR-93-5p inhibited migration, but not invasion of Caco 2 cells [27], suppressed migration of HCT116 cells [54], suppressed migration and invasion of SW480 and HCT116 cells [26], and LOVO and SW480 cells [56]. In line with the in vitro studies, miR-93-5p had a tumor-suppressor role on tumor growth in vivo. Mice injected subcutaneously with cells or miR-93-5p overexpression vectors had significantly smaller tumors in comparison to the control group $[54,27]$. Probably because these in vivo studies found a tumor-suppressive role of miR-93-5p, the precise effect of the increased miR-93-5p expression on CRLM was not presented. Considering our results of the potential prognostic function of circulating miR-93-5p in CRLM patients, further studies are needed to fully elucidate the role of miR-93-5p in colorectal cancer liver metastases.

To confirm the clinical findings, in vitro experiments were performed. The effect of systemic (FOX), targeted (bevacizumab), and combinational therapy (FOX/bevacizumab) for mCRC on the viability of normal and metastatic CRC cells and on miR-93-5p expression was studied in more detail because approximately $90 \%$ of study subjects who received neoadjuvant treatment, a combination of 5-FU/oxaliplatin/ bevacizumab was administered. FOX treatment was able to reduce the cell survival of SW620 and HCEC-1CT cells. The viability of HCEC-1CT cells was significantly dosedependently reduced under bevacizumab and FOX/bevacizumab treatments, while only the highest tested concentration of bevacizumab in combination with FOX was able to significantly reduce the viability of SW620 cells. In contrast 
to our results, Vuletic et al. showed that 25 and $50 \mu \mathrm{g} / \mathrm{ml}$ bevacizumab decreased significantly SW620 cell viability to approximately $90 \%$, whereas we were unable to observe cytotoxic effects even under $250 \mu \mathrm{g} / \mathrm{ml}$ bevacizumab [57]. Another study showed that $250 \mu \mathrm{g} / \mathrm{ml}$ bevacizumab had slightly increased proliferation of SW620, however, these cells were grown in hypoxic $\left(1 \% \mathrm{O}_{2}\right)$ and serum-reduced $(1 \%$ FBS) conditions [58]. Overall, HCEC-1CT cells were more sensitive to the tested drugs in comparison to the SW620 cells. It is not unusual for an anti-cancer drug to kill normal cells because it is known that 5-FU acts by interfering with DNA and RNA synthesis in both normal and tumor cells [59]. Although there is no literature data about the viability of HCEC-1CT cells treated with 5-FU, oxaliplatin, and bevacizumab, it was shown that 5-FU had a strong cytotoxic effect on CCD112, another normal colorectal cell line [60].

The basal miR-93-5p expression was higher in metastatic SW620 cells in comparison to normal HCEC-1CT cells. In contrast, Tang et al. observed lower miR-93-5p expression in SW620 cells but in comparison to the mean miR-93-5p expression level of normal colonic mucosa from 45 subjects [54]. We have shown that neoadjuvant chemotherapy does not affect CRLM and serum miR-93-5p levels in patients with CRLM and to confirm this finding, an in vitro experiment was set up. The effect of a targeted therapy agent bevacizumab on miR-93-5p expression has not yet been studied in vitro on the mCRC cell line model. We have shown that $250 \mu \mathrm{g} / \mathrm{ml}$ bevacizumab alone or in combination with FOX does not influence miR-93-5p expression in SW620 cells. In this study, miR-93-5p expression was stable even under FOX, which is in contrast to our previous findings where miR-93-5p expression was downregulated after $72 \mathrm{~h}$ of treatment with FOX in the same cell line [30]. The only difference in the two experimental settings was the endogenous control used, RNU6B, which was used in the previous study, and miR-16-5p which was used here, although both endogenous controls have been previously reported to have stable expression and were used for miRNA's expression normalization in SW620 cells [61, 37]. As in SW620 cells, bevacizumab did not have an effect on miR-93-5p expression in HCEC-1CT cells.

Patient data presented here showed that there was no statistically significant association between miR-93-5p expression and therapy responders vs. non-responders. To confirm this, we have made an in vitro 5-FU-resistant mCRC model since all of our study group subjects have received some form of 5-FU-based chemotherapy for CRLM. SW620 cells were known to have the highest tolerance to 5-FU in comparison to other CRC cell lines SW480, HCT116, HCT15, HCT8, HT-29, and LOVO cells [62]. Wide range of $5-\mathrm{FU} \mathrm{IC}_{50}$ values has been reported for SW620 cells, from as low as $0.5 \mu \mathrm{M}$ [63], 8-25 $\mu \mathrm{M}$ [64-67] to high as $100 \mu \mathrm{M}[68,69]$. We found a 5-FU IC I0 $_{50}$ value of $196.34 \mu \mathrm{M}$ which is higher in comparison to the literature data, however, it should be mentioned that these studies differ significantly in the treatment duration (from $24 \mathrm{~h}$ to $120 \mathrm{~h}$ ) and assay used to measure cell viability
(MTT, Cell Counting Kit-8 assay, and sulforhodamine assay). Generated SW620 5-FU resistant cells exhibited 1.8 5-FU fold resistance in comparison to the parental SW620 cells, which is close to the lower limit for clinically relevant fold resistance of 2 [70]. It was shown that miR-93-5p expression was similar in parental SW620 cells in comparison to the 5-FU resistant SW620 cells, thus confirming the lack of miR-93-5p chemosensitivity to 5-FU. Overall, in vitro data confirmed that miR-93-5p cannot be used as a predictive biomarker for CRLM therapy response follow-up.

The major limitation of this study is the relatively small sample size. Although 3 different samples were collected from each of the 35 patients with CRLM, the sample size could limit the power of statistical analysis, so further studies involving more CRLM patients are warranted in order to validate our preliminary results.

In conclusion, this is the first study to examine the predictive and prognostic value of miR-93-5p in mCRC patients either as tissue or circulating biomarker. We have shown that miR-93-5p could not be used as a predictive biomarker in CRLM patients treated with 5-FU-based chemotherapy, however, since high miR-93-5p serum levels were significantly associated with early disease recurrence, circulating miR-93-5p levels could serve as a prognostic factor for early disease recurrence in CRLM patients after liver resection. Further large-scale studies are warranted to confirm circulating miR-93-5p prognostic capacity.

Acknowledgments: This article is based upon work from COST Action CA17118, supported by COST (European Cooperation in Science and Technology) www.cost.eu. This work was supported by the Ministry of Education, Science and Technological Development of the Republic of Serbia [451-03-9/2021-14/200042] and the Serbian Academy of Science and Arts [F-69].

\section{References}

[1] BRAY F, FERLAY J, SOERJOMATARAM I, SIEGEL RL, TORRE LA et al. Global cancer statistics 2018: GLOBOCAN estimates of incidence and mortality worldwide for 36 cancers in 185 countries. CA Cancer J Clin 2018; 68: 394-424. https://doi.org/10.3322/caac.21492

[2] HESS KR, VARADHACHARY GR, TAYLOR SH, WEI W, RABER MN et al. Metastatic patterns in adenocarcinoma. Cancer 2006; 106: 1624-1633. https://doi.org/10.1002/ cncr.21778

[3] VAN CUTSEM E, CERVANTES A, NORDLINGER B, ARNOLD D, GROUP EGW. Metastatic colorectal cancer: ESMO Clinical Practice Guidelines for diagnosis, treatment and follow-up. Ann Oncol 2014; 25 Suppl 3: iii1-9. https:// doi.org/10.1093/annonc/mdu260

[4] HUGEN N, VAN DE VELDE CJ, DE WILT JH, NAGTEGAAL ID. Metastatic pattern in colorectal cancer is strongly influenced by histological subtype. Ann Oncol 2014; 25: 651-657. https://doi.org/10.1093/annonc/mdt591 
[5] HELLING TS, MARTIN M. Cause of death from liver metastases in colorectal cancer. Ann Surg Oncol 2014; 21: 501506. https://doi.org/10.1245/s10434-013-3297-7

[6] ADAMR,DELVARTV,PASCALG,VALEANUA,CASTAING $D$ et al. Rescue surgery for unresectable colorectal liver metastases downstaged by chemotherapy: a model to predict longterm survival. Ann Surg 2004; 240: 644-657; discussion 657648. https://doi.org/10.1097/01.sla.0000141198.92114.f6

[7] SCHEELE J, STANG R, ALTENDORF-HOFMANN A, PAUL M. Resection of colorectal liver metastases. World J Surg 1995; 19: 59-71. https://doi.org/10.1007/BF00316981

[8] CHOTI MA, SITZMANN JV, TIBURI MF, SUMETCHOTIMETHA W, RANGSIN $\mathrm{R}$ et al. Trends in longterm survival following liver resection for hepatic colorectal metastases. Ann Surg 2002; 235: 759-766. https://doi. org/10.1097/00000658-200206000-00002

[9] DE GRAMONT A, FIGER A, SEYMOUR M, HOMERIN M, HMISSI A et al. Leucovorin and fluorouracil with or without oxaliplatin as first-line treatment in advanced colorectal cancer. J Clin Oncol 2000; 18: 2938-2947. https://doi. org/10.1200/JCO.2000.18.16.2938

[10] DOUILLARD JY, CUNNINGHAM D, ROTH AD, NAVARRO M, JAMES RD et al. Irinotecan combined with fluorouracil compared with fluorouracil alone as first-line treatment for metastatic colorectal cancer: a multicentre randomised trial. Lancet 2000; 355: 1041-1047. https://doi.org/10.1016/ s0140-6736(00)02034-1

[11] CREMOLINI C, SCHIRRIPA M, ANTONIOTTI C, MORETTO R, SALVATORE L et al. First-line chemotherapy for $\mathrm{mCRC}-\mathrm{a}$ review and evidence-based algorithm. Nat Rev Clin Oncol 2015; 12: 607-619. https://doi.org/10.1038/nrclinonc.2015.129

[12] HEINEMANN V, VON WEIKERSTHAL LF, DECKER T, KIANI A, VEHLING-KAISER U et al. FOLFIRI plus cetuximab versus FOLFIRI plus bevacizumab as first-line treatment for patients with metastatic colorectal cancer (FIRE-3): a randomised, open-label, phase 3 trial. Lancet Oncol 2014; 15: 1065-1075. https://doi.org/10.1016/S14702045(14)70330-4

[13] VAN CUTSEM E, LENZ HJ, KÖHNE CH, HEINEMANN V, TEJPAR $S$ et al. Fluorouracil, leucovorin, and irinotecan plus cetuximab treatment and RAS mutations in colorectal cancer. J Clin Oncol 2015; 33: 692-700. https://doi.org/10.1200/ JCO.2014.59.4812

[14] DOUILLARD JY, OLINER KS, SIENA S, TABERNERO J, BURKES R et al. Panitumumab-FOLFOX4 treatment and RAS mutations in colorectal cancer. N Engl J Med 2013; 369: 1023-1034. https://doi.org/10.1056/NEJMoa1305275

[15] TRAN B, KOPETZ S, TIE J, GIBBS P, JIANG ZQ et al. Impact of BRAF mutation and microsatellite instability on the pattern of metastatic spread and prognosis in metastatic colorectal cancer. Cancer 2011; 117: 4623-4632. https://doi. org/10.1002/cncr.26086

[16] LO NIGRO C, RICCI V, VIVENZA D, GRANETTO C, FABOZZI T et al. Prognostic and predictive biomarkers in metastatic colorectal cancer anti-EGFR therapy. World J Gastroenterol 2016; 22: 6944-6954. https://doi.org/10.3748/ wjg.v22.i30.6944
[17] TAIEB J, JUNG A, SARTORE-BIANCHI A, PEETERS M, SELIGMANN J et al. The Evolving Biomarker Landscape for Treatment Selection in Metastatic Colorectal Cancer. Drugs 2019; 79: 1375-1394. https://doi.org/10.1007/s40265-01901165-2

[18] BARTEL DP. Metazoan MicroRNAs. Cell 2018; 173: 20-51. https://doi.org/10.1016/j.cell.2018.03.006

[19] MICHAEL MZ, O' CONNOR SM, VAN HOLST PELLEKAAN NG, YOUNG GP, JAMES RJ. Reduced accumulation of specific microRNAs in colorectal neoplasia. Mol Cancer Res 2003; 1: 882-891.

[20] ROSSI S, KOPETZ S, DAVULURI R, HAMILTON SR, CALIN GA. MicroRNAs, ultraconserved genes and colorectal cancers. Int J Biochem Cell Biol 2010; 42: 1291-1297. https://doi.org/10.1016/j.biocel.2009.05.018

[21] XIE T, HUANG M, WANG Y, WANG L, CHEN C et al. MicroRNAs as Regulators, Biomarkers and Therapeutic Targets in the Drug Resistance of Colorectal Cancer. Cell Physiol Biochem 2016; 40: 62-76. https://doi.org/10.1159/000452525

[22] MASUDA T, HAYASHI N, KURODA Y, ITO S, EGUCHI $\mathrm{H}$ et al. MicroRNAs as Biomarkers in Colorectal Cancer. Cancers (Basel) 2017; 9: 124. https://doi.org/10.3390/cancers 9090124

[23] SCHOU JV, JOHANSEN JS, NIELSEN D, ROSSI S. Circulating microRNAs as Prognostic and Predictive Biomarkers in Patients with Colorectal Cancer. Noncoding RNA 2016; 2: 5. https://doi.org/10.3390/ncrna2020005

[24] PETROCCAF, VECCHIONEA,CROCECM.Emergingroleof miR-106b-25/miR-17-92 clusters in the control of transforming growth factor beta signaling. Cancer Res 2008; 68: 81918194. https://doi.org/10.1158/0008-5472.CAN-08-1768

[25] XIAO ZG, DENG ZS, ZHANG YD, ZHANG Y, HUANG ZC. Clinical significance of microRNA-93 downregulation in human colon cancer. Eur J Gastroenterol Hepatol 2013; 25: 296-301. https://doi.org/10.1097/MEG.0b013e32835c077a

[26] CHEN YL, WANG GX, LIN BA, HUANG JS. MicroRNA93-5p expression in tumor tissue and its tumor suppressor function via targeting programmed death ligand-1 in colorectal cancer. Cell Biol Int 2020; 44: 1224-1236. https:// doi.org/10.1002/cbin.11323

[27] YANG IP, TSAI HL, HOU MF, CHEN KC, TSAI PC et al. MicroRNA-93 inhibits tumor growth and early relapse of human colorectal cancer by affecting genes involved in the cell cycle. Carcinogenesis 2012; 33: 1522-1530. https://doi. org/10.1093/carcin/bgs166

[28] FANG L, DENG Z, SHATSEVA T, YANG J, PENG C et al. MicroRNA miR-93 promotes tumor growth and angiogenesis by targeting integrin- $\beta 8$. Oncogene $2011 ; 30$ : 806-821. Oncogene 2011; 30: 806-821

[29] TANG Q, ZOU Z, ZOU C, ZHANG Q, HUANG R et al. MicroRNA-93 suppress colorectal cancer development via Wnt/ß-catenin pathway downregulating. Tumour Biol 2015; 36: 1701-1710. https://doi.org/10.1007/s13277-014-2771-6

[30] DESPOTOVIC J, DRAGICEVIC S, NIKOLIC A. Effects of Chemotherapy for Metastatic Colorectal Cancer on the TGF-beta Signaling and Related miRNAs hsa-miR-17-5p, hsa-miR-21-5p and hsa-miR-93-5p. Cell Biochem Biophys 2021; 79: 757-767. https://doi.org/10.1007/s12013-02100980-3 
[31] YANG IP, TSAI HL, MIAO ZF, HUANG CW, KUO CH et al. Development of a deregulating microRNA panel for the detection of early relapse in postoperative colorectal cancer patients. J Transl Med 2016; 14: 108. https://doi.org/10.1186/ s12967-016-0856-2

[32] LU JF, BRUNO R, EPPLER S, NOVOTNY W, LUM B et al. Clinical pharmacokinetics of bevacizumab in patients with solid tumors. Cancer Chemother Pharmacol 2008; 62: 779786. https://doi.org/10.1007/s00280-007-0664-8

[33] ZHI J, CHEN E, MAJOR P, BURNS I, ROBINSON B et al. A multicenter, randomized, open-label study to assess the steady-state pharmacokinetics of bevacizumab given with either XELOX or FOLFOX-4 in patients with metastatic colorectal cancer. Cancer Chemother Pharmacol 2011; 68: 1199-1206. https://doi.org/10.1007/s00280-011-1606-Z

[34] LISTON DR, DAVIS M. Clinically Relevant Concentrations of Anticancer Drugs: A Guide for Nonclinical Studies. Clin Cancer Res 2017; 23: 3489-3498. https://doi. org/10.1158/1078-0432.CCR-16-3083

[35] BOGDANOVIC A, DESPOTOVIC J, GALUN D, BIDZIC N, NIKOLIC A et al. Prognostic Significance of. Cancer Manag Res 2021; 13: 163-171. https://doi.org/10.2147/CMAR. S287974

[36] DAS MK, ANDREASSEN R, HAUGEN TB, FURU K. Identification of Endogenous Controls for Use in miRNA Quantification in Human Cancer Cell Lines. Cancer Genomics Proteomics 2016; 13: 63-68.

[37] ZHANG Y, HE X, LIU Y, YE Y, ZHANG H et al. microRNA320a inhibits tumor invasion by targeting neuropilin 1 and is associated with liver metastasis in colorectal cancer. Oncol Rep 2011; 27: 685-694. https://doi.org/10.3892/or.2011.1561

[38] CHANG KH, MESTDAGH P, VANDESOMPELE J, KERIN MJ, MILLER N. MicroRNA expression profiling to identify and validate reference genes for relative quantification in colorectal cancer. BMC Cancer 2010; 10: 173. https://doi. org/10.1186/1471-2407-10-173

[39] XIANG M, ZENG Y, YANG R, XU H, CHEN Z et al. U6 is not a suitable endogenous control for the quantification of circulating microRNAs. Biochem Biophys Res Commun 2014; 454: 210-214. https://doi.org/10.1016/j.bbrc.2014.10.064

[40] MÜLLER V, GADE S, STEINBACH B, LOIBL S, VON MINCKWITZ $G$ et al. Changes in serum levels of miR-21, miR-210, and miR-373 in HER2-positive breast cancer patients undergoing neoadjuvant therapy: a translational research project within the Geparquinto trial. Breast Cancer Res Treat 2014; 147: 61-68. https://doi.org/10.1007/s10549014-3079-3

[41] GREEN MR, SAMBROOK J. Analysis and Normalization of Real-Time Polymerase Chain Reaction (PCR) Experimental Data. Cold Spring Harb Protoc 2018; 2018. https://doi. org/10.1101/pdb.top095000

[42] EISENHAUER EA, THERASSE P, BOGAERTS J, SCHWARTZ LH, SARGENT D et al. New response evaluation criteria in solid tumours: revised RECIST guideline (version 1.1). Eur J Cancer 2009; 45: 228-247. https://doi. org/10.1016/j.ejca.2008.10.026
[43] ULIVI P, CANALE M, PASSARDI A, MARISI G, VALGIUSTI $M$ et al. Circulating Plasma Levels of miR-20b, miR-29b and miR-155 as Predictors of Bevacizumab Efficacy in Patients with Metastatic Colorectal Cancer. Int J Mol Sci 2018; 19: 307. https://doi.org/10.3390/ijms19010307

[44] KULDA V, PESTA M, TOPOLCAN O, LISKA V, TRESKA $\mathrm{V}$ et al. Relevance of miR-21 and miR-143 expression in tissue samples of colorectal carcinoma and its liver metastases. Cancer Genet Cytogenet 2010; 200: 154-160. https://doi. org/10.1016/j.cancergencyto.2010.04.015

[45] LIANG Y, RIDZON D, WONG L, CHEN C. Characterization of microRNA expression profiles in normal human tissues. BMC Genomics 2007; 8: 166. https://doi.org/10.1186/14712164-8-166

[46] DRUSCO A, NUOVO GJ, ZANESI N, DI LEVA G, PICHIORRI $F$ et al. MicroRNA profiles discriminate among colon cancer metastasis. PLoS One 2014; 9: e96670. https://doi. org/10.1371/journal.pone.0096670

[47] PESTA M, KUCERA R, TOPOLCAN O, KARLIKOVA M, HOUFKOVA $\mathrm{K}$ et al. Plasma microRNA Levels Combined with CEA and CA19-9 in the Follow-Up of Colorectal Cancer Patients. Cancers (Basel) 2019; 11: 864. https://doi. org/10.3390/cancers11060864

[48] RAPADO-GONZÁLEZ Ó, ÁLVAREZ-CASTRO A, LÓPEZLÓPEZ R, IGLESIAS-CANLE J, SUÁREZ-CUNQUEIRO $\mathrm{MM}$ et al. Circulating microRNAs as Promising Biomarkers in Colorectal Cancer. Cancers (Basel) 2019; 11: 898. https:// doi.org/10.3390/cancers11070898

[49] WANG LG, GU J. Serum microRNA-29a is a promising novel marker for early detection of colorectal liver metastasis. Cancer Epidemiol 2011; 36: e61-67. https://doi.org/10.1016/j. canep.2011.05.002

[50] GMEREK L, MARTYNIAK K, HORBACKA K, KROKOWICZ P, SCIERSKI W et al. MicroRNA regulation in colorectal cancer tissue and serum. PLoS One 2019; 14: e0222013. https://doi.org/10.1371/journal.pone.0222013

[51] TO KK, TONG CW, WU M, CHO WC. MicroRNAs in the prognosis and therapy of colorectal cancer: From bench to bedside. World J Gastroenterol 2018; 24: 2949-2973. https:// doi.org/10.3748/wjg.v24.i27.2949

[52] RASMUSSEN MH, JENSEN NF, TARPGAARD LS, QVORTRUP C, RØMER MU et al. High expression of microRNA-625-3p is associated with poor response to first-line oxaliplatin based treatment of metastatic colorectal cancer. Mol Oncol 2013; 7: 637-646. https://doi.org/10.1016/j. molonc.2013.02.016

[53] YU XF, ZOU J, BAO ZJ, DONG J. miR-93 suppresses proliferation and colony formation of human colon cancer stem cells. World J Gastroenterol 2011; 17: 4711-4717. https://doi. org/10.3748/wjg.v17.i42.4711

[54] TANG Q, ZOU Z, ZOU C, ZHANG Q, HUANG R et al. MicroRNA-93 suppress colorectal cancer development via Wnt/ $\beta$-catenin pathway downregulating. Tumour Biol 2014; 36: 1701-1710. https://doi.org/10.1007/s13277-014-2771-6

[55] LIU Y, CHEN X, LIU J, GU H, FAN R et al. Long non-coding RNA HOTAIR knockdown enhances radiosensitivity through regulating microRNA-93/ATG12 axis in colorectal cancer. Cell Death Dis 2020; 11: 175. https://doi.org/10.1038/ s41419-020-2268-8 
[56] GU M, JIANG Z, LI H, PENG J, CHEN X et al. MiR-93/ HMGB3 regulatory axis exerts tumor suppressive effects in colorectal carcinoma cells. Exp Mol Pathol 2021; 120: 104635. https://doi.org/10.1016/j.yexmp.2021.104635

[57] VULETIC I, ZHOU K, LI H, BAI H, MENG X et al. Validation of Bevacizumab Therapy Effect on Colon Cancer Subtypes by Using Whole Body Imaging in Mice. Mol Imaging Biol 2017; 19: 847-856. https://doi.org/10.1007/s11307-0171048-Z

[58] HEIN M, GRAVER S. Tumor cell response to bevacizumab single agent therapy in vitro. Cancer Cell Int 2013; 13: 94. https://doi.org/10.1186/1475-2867-13-94

[59] LONGLEY DB, HARKIN DP, JOHNSTON PG. 5-fluorouracil: mechanisms of action and clinical strategies. Nat Rev Cancer 2003; 3: 330-338. https://doi.org/10.1038/nrc1074

[60] YUSEFI M, SHAMELI K, JAHANGIRIAN H, TEOW SY, UMAKOSHI $\mathrm{H}$ et al. The Potential Anticancer Activity of 5-Fluorouracil Loaded in Cellulose Fibers Isolated from Rice Straw. Int J Nanomedicine 2020; 15: 5417-5432. https://doi. org/10.2147/IJN.S250047

[61] LONG L, HUANG G, ZHU H, GUO Y, LIU Y et al. Downregulation of miR-138 promotes colorectal cancer metastasis via directly targeting TWIST2. J Transl Med 2013; 11: 275. https://doi.org/10.1186/1479-5876-11-275

[62] CHAI J, DONG W, XIE C, WANG L, HAN DL et al. MicroRNA-494 sensitizes colon cancer cells to fluorouracil through regulation of DPYD. IUBMB Life 2015; 67: 191-201. https:// doi.org/10.1002/iub.1361

[63] RUIHUA H, MENGYI Z, CHONG Z, MENG Q, XIN M et al. RhoA regulates resistance to irinotecan by regulating membrane transporter and apoptosis signaling in colorectal cancer. Oncotarget 2016; 7: 87136-87146. https://doi. org/10.18632/oncotarget.13548
[64] FISCHEL JL, ROSTAGNO P, FORMENTO P, DUBREUIL A, ETIENNE MC et al. Ternary combination of irinotecan, fluorouracil-folinic acid and oxaliplatin: results on human colon cancer cell lines. Br J Cancer 2001; 84: 579-585. https:// doi.org/10.1054/bjoc.2000.1600

[65] MATUO R, SOUSA FG, ESCARGUEIL AE, GRIVICICH I, GARCIA-SANTOS D et al. 5-Fluorouracil and its active metabolite FdUMP cause DNA damage in human SW620 colon adenocarcinoma cell line. J Appl Toxicol 2009; 29: 308-316. https://doi.org/10.1002/jat.1411

[66] MANS DR, GRIVICICH I, PETERS GJ, SCHWARTSMANN G. Sequence-dependent growth inhibition and DNA damage formation by the irinotecan-5-fluorouracil combination in human colon carcinoma cell lines. Eur J Cancer 1999; 35: 1851-1861. https://doi.org/10.1016/s0959-8049(99)00222-1

[67] GONZÁLEZ-VALLINAS M, MOLINA S, VICENTE G, DE LA CUEVA A, VARGAS T et al. Antitumor effect of 5-fluorouracil is enhanced by rosemary extract in both drug sensitive and resistant colon cancer cells. Pharmacol Res 2013; 72: 61-68. https://doi.org/10.1016/j.phrs.2013.03.010

[68] TONG J, XIE G, HE J, LI J, PAN F et al. Synergistic antitumor effect of dichloroacetate in combination with 5-fluorouracil in colorectal cancer. J Biomed Biotechnol 2011; 2011: 740564. https://doi.org/10.1155/2011/740564

[69] SHEN L, YU M, XU X, GAO L, NI J et al. Knockdown of $\beta 3 \mathrm{GnT} 8$ reverses 5 -fluorouracil resistance in human colorectal cancer cells via inhibition the biosynthesis of polylactosamine-type N-glycans. Int J Oncol 2014; 45: 2560-2568. https://doi.org/10.3892/ijo.2014.2672

[70] MCDERMOTT M, EUSTACE AJ, BUSSCHOTS S, BREEN L, CROWN J et al. In vitro Development of Chemotherapy and Targeted Therapy Drug-Resistant Cancer Cell Lines: A Practical Guide with Case Studies. Front Oncol 2014; 4: 40. https://doi.org/10.3389/fonc.2014.00040 